\title{
Stock Market development and economic growth. Should we be concerned about
}

measurement?

\author{
Richard Darko
}

Department of Economics, University Of Northern British Columbia, 3333 University Way, Prince George, BC, Canada V2N 4Z9

Corresponding Author's Email Address: darko@unbc.ca

Phone number: +1 6478227076

\begin{abstract}
Does the choice of proxy for stock market development matter? This paper suggests that the growth effect of stock market development is sensitive to the choice of proxy and using alternative financial development indicators have practically no influence on the results. We found that using either the stock market capitalization to GDP ratio or the stock market returns; have a positive and significant effect on growth. However, we cannot make same conclusion when one uses either the ratio of total value of trades on the major stock exchanges to GDP or stock market turnover ratio to proxy for stock market development as the coefficient on these variables were found to be statistically insignificant. The indexes extracted from principal component analysis confirm the sensitivity of the effect to the choice of proxy. This finding suggest that stock market development is a conceptual terms, thus, representing it with single indicators make it impossible to identify which stock market development indicators have a significant positive growth effects.
\end{abstract}

Keywords: Economic growth, Principal Component analysis, Cointegration, Stock market development, financial market development 


\section{Introduction}

There is a growing body of literature on the link between stock market development and economic growth. Theoretical evidence suggests that stock market provides services that contribute to longrun growth (Bencivenga, Smith, and Starr (1996) and Levine (1991), Kyle (1984) and Holmstrom and Tirole (1993), Fi Obstfeld (1994). In particular, Greenwood and Smith (1997) opined that large stock markets can lead to a lower cost of mobilizing savings and thus, facilitates capital resources for productive activities. On the contrary, others have argued that greater risk sharing associated with internationally integrated stock markets can cause a reduction in saving rates and thereby retard economic growth (Devereux and Smith, 1994). According to (Shleifer and Summers (1988) and Morck, Shleifer, and Vishny (1990a, 1990b) stock market development can impede economic growth by easing counterproductive corporate takeovers. In simple put, many observers have argued that financial markets are not associated with long-run growth whiles others have suggested that the financial market is a 'vehicle' for mobilising saving, allocating capital, inculcating corporate control and easing risk associated with investment.

The preceding arguments have become a subject of empirical investigation over the past two decades to ascertain whether indeed financial system is anyway connected to long-run growth. As far as the existing stock market development and growth literature is concerned; there is no clearcut evidence that lends credence to the hypothesis that stock market development impacts positively on economic growth.

Earlier studies by (Levine and Zervos, 1996, 1998) based on cross-country growth regressions suggest a strong positive relationship between stock market development and long-run economic growth. On the contrary, this evidence is weak as far as country-specific growth regressions are concerned. Particularly, Arestis etal (2001) posited that cross-country regression misses out some 
unique characteristics of individual countries and thus, fail to provide a clear picture of the relationship between stock market and economic growth. We need to be concerned about how stock market development is measured and which of the indicators can appropriately represent Stock market development. Stock market development is a theoretical concept which in practical terms depicts the size, liquidity and volatility of the market. Using any of one of the above measures to proxy for stock market development may not provide a full understanding of the concept and thus, their coefficients cannot provide conclusive evidence but can only be interpreted as partial effects. In modelling, we utilise the principal component analysis to extract information in the above-mentioned measures to form four indexes or factors which are then applied in a growth regression. This approach appeal more to theory than using single indicator since in the real world, stock market development is unobservable. In the same vein, the indexes created by the principal component analysis are also unobservable. Therefore, it is reasonable to assume that the four indexes statistically measure stock market development. However, we are unsure of the impact of these indexes on growth. Thus, this paper empirically examines the impact of stock market development in a data-driven environment. Does measurement really matter?

The aim of this paper is to examine the impact of stock market development on long-run growth. This paper is empirically unique in terms of how we measure stock market development using the principal components analysis. Unlike using the traditional stock market indicators as proxies for stock market development, we utilise the principal components analysis to create four indexes from five stock market indicators mainly used in the literature to represent stock market development.

We find that the growth effect of stock market development is sensitive to the choice of proxy used. For instance, using either the stock market capitalization to GDP ratio or the stock market 
returns, we found positive and significant effect of stock market development on growth. This result is sharply contrasted with Arestis etal (2001). However, we cannot make same conclusion when one uses either the ratio of total value of trades on the major stock exchanges to GDP, stock market turnover ratio to proxy for stock market development as the coefficient of these variables were found to be statistically insignificant. The indexes created from principal component analysis confirm the sensitivity of the growth effect to the choice of proxy. We conclude that it will be econometrically disastrous for one to rely on a single indicator or on the approach prescribed by Levine and Zervos $(1996,1998)$ by simply averaging the individual indicators across time to obtain a single index of stock market development. Using the above mentioned indicators, we are unable to identify which stock market development variable has positive growth enhancing effect and which does not. Lastly, using different financial development indicators or indexes (ie. created by principal component analysis) did not have any practical effect on our results. This implies that financial sector development is not necessarily a precondition for stock market development to have a positive impact on growth but a component of the financial market.

The rest of the paper is organized as follows. Section 2 presents a detailed review of empirical literature on stock market development and economic growth. Section 3 deals with estimation techniques and data issues. The results and discussions are reported in Section 4. Section 5 concludes the paper with summary of findings.

\section{Review of Related Literature}

The empirical literature lends credence to a positive relationship between financial markets and economic growth. This proposition was first examined by Goldsmith (1969) using data sets from 
35 countries between 1860 and 1963. This work received a lot of criticism because it failed to control for other relevant variables that can affect growth. Also no specific conclusion was made regarding causality or the relative importance of various transmission channels. King and Levine (1993a) is seen as the starting point for intense empirical research on the financial sector and growth relationship. This study combined cross-country, time series and panel data analysis. Using a sample of 80 countries between the period 1960 and 1989, King and Levine (1993b) reported that the initial level of financial development is a good predictor of the economic growth. In recent years, some studies attempt to examine the relationship between stock market development and economic growth. A pioneered work by Atje and Jovanovic (1993) suggested that stock market has positive effects on economic growth. Levine and Zervos (1996) and subsequent work in 1998 confirmed their findings. Levine and Zervos (1996) adopted pooled cross country time series regression on stock market development and economic growth using a data set from 1976 to 1993 . The paper showed that cross-country growth regressions suggest that the predetermined component of stock market development is positively and robustly associated with long-run economic growth. The authors argued that their finding is not conclusive and should be viewed as suggestive partial relationship that should stimulate further research. In particular, the paper advised that future work must focus more on country specific analysis and also identify policies that will ease sound securities market development.

Again, Levine and Zervos (1998) extended the argument to include banking development using GDP growth, capital accumulation, and productivity as dependent variables. Unlike previous work, this paper studied the empirical relationship between various measures of stock market development, banking development, and long-run economic growth. The paper found that stock 
market liquidity and banking development both positively predict growth, capital accumulation, and productivity improvements when entered together in regressions, even after controlling for other factors are connected with growth. The results are in line with the views that financial markets are crucial for growth, and that stock markets provide variety of services from banks. A recent work by Mishra and Pan (2018) investigates the relationship between the stock market and the real economy using Chinese data. Applying unit root testing in the presence of structural breaks and the Autoregressive distributed lag (ARDL) model, the paper reports that the Shanghai A share market has a negative long-run relationship with the real economy; however, the magnitude of impact is infinitesimal. The authors argued that their finding is a proof of existence of irrational prosperity in the stock market and the growth spurt in China's financial sector. Using Toda Yamamoto causality test, the paper showed that economic growth has facilitated the development of the Shenzhen B share market.

Cross-country analysis is problematic because it uses instrumental variables to deal with the endogeneity problem associated with cross sectional regressions. However, according to Ahmed (1998), the instrumental variable approach is useless when it comes to potential reverse causality problem in the relationship between economic growth and financial markets using a long dataset. Harris (1997) showed that there exist shortages in grouping countries. Using the same data source as Atje and Jovanovic's (1993), Harris found that the former's results were not robust. Also, Garrestsen et al. (2004) disputed the positive relationship between stock market and economic growth discovered by Levine and Zervos (1998) when legal and other societal factors were controlled for. Based on the above review, it is reasonable to conclude that the general 
findings of cross-country studies are not consistent. In addition, they are sensitive to the number of sample countries, independent variables, time horizon and methodology.

Gupta (1984) employed a time series analysis to examine finance - growth nexus. He found unidirectional causality from financial market development to economic growth. Also, Neusser and Kugler (1998) adopted financial sector GDP and manufacturing GDP as proxies for financial market development and economic growth, respectively. Their findings were in line with later studies (e.g., Choe and Moosa, 1999; Xu, 2000; Rousseau and Vuthipadadorn, 2005). However, time series regression is beset with short sample period in most of the analysis. Time series regression requires a lengthy study period to account for time dynamics which is embedded in most macroeconomic series.

In recent times, because of the shortcomings of cross-sectional studies, researchers have employed panel data techniques to study the relationship between financial development and economic growth. A plethora of studies (e.g., Beck. et al., 2000; Rousseau and Wachtel, 2000; Beck and Levine, 2004) confirmed that financial development is positively related to economic growth. Because of several problems such as limited data points and spurious regression, Christopoulos and Tsionas (2004) suggested that the causality pattern could be examined by applying panel unit root and panel cointegration tests. In their analysis, they found only a uni-directional causality running from financial development to economic growth. Other studies (e.g., Rajan and Zingales, 1998; Fisman and Love, 2003; Allen et al., 2005) investigated the topic at the micro level by using firm or industry level data to supplement cross-country studies. However, the conclusions drawn from the panel regressions were also criticised. Pesaran and Smith (1995) argued that the omitted 
variable or heterogeneity bias could not be resolved when the error terms include country-specific effects, which could lead to biased estimation results and inconsistent conclusions.

\section{Data and Methodology}

\section{a. Data and measurement}

We employ yearly data on gross domestic product, indicators of stock market development (ie. the ratio stock market capitalization to GDP $(S M C / Y)$, stock market volatility $(S M V)$, the ratio of total value of trades on the major stock exchanges to GDP $(S M T V / Y)$, stock market turnover ratio $(S M T O R)$ and stock market returns $(S M R))$, financial market development indicators (ie. broad money supply/GDP ( $M 2 / Y)$, domestic credit/GDP $(C D / Y)$, liquidity/GDP $(L Q T Y / Y)$ and private sector credit/Y $(C S P / Y))$, consumer price index $(C P I)$ as a measure of macroeconomic stability and trade openness (ie. defined as the sum of export and import/GDP) from 1975 - 2015. Our indicators of stock market and financial market development are carefully selected to reflect their relevance in the financial sector and also as most often used in the literature. All the datasets were converted into real values.

\section{b. Methodology}

This study utilizes the autoregressive distributed lag model (ARDL) to examine the existence of a long-run relationship between real GDP, stock market development, financial market development, inflation, and trade openness. According to Pesaran and Shin (1995), Pesaran and Smith (1997), and Pesaran et al. (2001) the ARDL bound testing could be used irrespective of the order of integration of the underlying variables being $I(0)$ and or $I(1))$ provided the absence of $I(2)$ variables are guaranteed which could result in spurious conclusion. Also, the ARDL approach 
usually produces unbiased estimates of the long-run model, and the resulting t-statistics are valid even if some of the regressors are endogenous (Harris and Sollis 2003). According to Pesaran and Shin (1995), the long-term coefficients are highly consistent, and their long-term parameters can be inferred using standard asymptotic theory.

We specify our empirical model as follows;

$Y_{t}=\beta_{0}+\beta_{1} S M D_{t}+\beta_{2} F D_{t}+\beta_{3} C P I_{t}+\beta_{4} O P E N_{t}+\beta_{5} F I N C D U M+\varepsilon_{t}$

where $Y$ is real output (proxied by real GDP); CPI denotes inflation; Open - the level of trade openness of the economy (proxied by the ratio of the sum of exports and imports to GDP ratio); $F D$ denotes a vector of proxies for financial development comprising broad money/GDP $(M 2+/ Y)$; private-sector credit/GDP $(C P S / Y)$, total domestic credit/GDP $(D C / Y)$ and Total bank deposit liabilities/GDP $(D e p / Y)$. SMD represents a vector of stock market development indicators including the ratio stock market capitalization to GDP $(S M C / Y)$, stock market volatility $(S M V)$, the ratio of total value of trades on the major stock exchanges to GDP $(S M T V / Y)$, stock market turnover ratio (SMTOR and stock market returns (SMR), and FINCDUM represents a dummy for various financial crisis that has hit the US economy during the period understudy. It assumes the value 1 for the period 1981-1982, 1986 - 1995, 2000 - 2001, 2007 - 2009 (period for which US economy was plunged into financial crisis and zero for the years without economic downturns and $\varepsilon_{t}$ is an error term. All variables are in natural logarithm except FINCDUM.

The equation form for the ARDL model is expressed as;

$$
\begin{aligned}
& \Delta \ln \left(Y_{t}\right)=\beta_{0}+\sum_{i=1}^{n} \varphi_{\mathrm{i}} \Delta \ln \left(Y_{t-1}\right)+\sum_{i=1}^{n} \lambda_{\mathrm{i}} \Delta \ln \left(S M D_{t-1}\right)+\sum_{i=1}^{n} \gamma_{\mathrm{i}} \Delta \ln \left(F D_{t-1}\right)+ \\
& \sum_{i=1}^{n} \omega \mathrm{i} \Delta\left(C P I_{t-1}\right)+\theta_{\mathrm{i}} \Delta \ln \left(O P E N_{t-1}\right)+\alpha_{1} \Delta \ln \left(Y_{t-1}\right)+\alpha_{2} \Delta \ln \left(S M D_{t-1}\right)+\alpha_{3} \Delta \ln \left(F D_{t-1}\right) \\
& +\alpha_{4} \Delta \ln \left(C P I_{t-1}\right)+\alpha_{5} \Delta \ln \left(O P E N_{t-1}\right)+v E C T_{t-1}+\varepsilon_{t}
\end{aligned}
$$


where all variables are as previously defined, $\beta_{0}$ is the drift component, $\Delta$ denotes difference operator and $\varepsilon_{t}$ is the white noise error term.

Our next step is to test for existence of long-run relationship among the variables using an $F$ statistic. The null hypothesis in Eq. (2) can be specified as $H_{0}: \alpha_{1}=\alpha_{2}=\alpha_{3}=\alpha_{4}=\alpha_{5}=0$ implying no long-run relationship and an alternative hypothesis suggesting an existence of cointegration ie. $H_{1}: \alpha_{1} \neq \alpha_{2} \neq \alpha_{3} \neq \alpha_{4} \neq \alpha_{5} \neq 0$. The computed $F$-statistics is compared with two sets of critical ( $1 \%$ and 5\%) values estimated by Pesaran et al. (2001) which composes of a lower critical bounds $(I(0))$ and upper critical value bounds $(I(1))$ for appropriate statistical conclusion regarding cointegration to be made. The decision rule is that if the computed $F$-stat exceeds the upper critical value, the null hypothesis of no cointegration is rejected, otherwise we accept the null. Optimal lag length for our growth model is selected based on Akaike Information Criterion (AIC).

\section{Empirical results and analysis}

This section presents and discusses the empirical results of the paper. Following Adu etal (2013), we utilise principal component analysis to reduce the dimension of both stock market development and financial development indicators into four sub-component indexes (unobserved factors). According to them, none of the financial market indicators used in the literature can adequately measure financial development, hence the need to create common factors from those indicators. Also, due to high correlation among these indicators we are unable to use more than one proxy indicator for stock market development in a single equation. Thus, we employ principal component analysis to extract information in all the indicators, while at the same time escaping the trap of multicollinearity by including more than one proxy in a single equation. In the next stage of the analysis, we investigate the time series properties of the individual series that we use in this paper, 
using unit root tests technique. Lastly, we test for the existence of cointegration among the variables by using the ARDL bounds test approach to cointegration analysis.

\section{Principal component analysis}

We use the principal component analysis to create four common factors for stock market development and financial development based on their proxy indicators. We present the results of principal component analysis from which the four indexes for stock market and financial development are created in Table 2 and 3 respectively. In respect of stock market development, the first four common factors extracted by principal components analysis explain about $99.95 \%$ of the total variance in the original data. Thus, we have been able to preserve almost all the information in the data. Furthermore, the common factors created are orthogonal to each other and thus are not correlated to each other. This allows us to include all the four factors in a single equation. The first principal component, SIndex1, explains about $59.5 \%$ of the total variance in the data. Using scoring coefficient of 0.3 or higher to determine the significance of factor score, the first principal components could be thought of as representing the variables $S M C / Y$, SMTOR and $S M T V / Y$. We can see that the scoring coefficient on two indicators in this component, $S M V$ and $S M R$ are lower than 0.3 and are thus treated as insignificant. The second, third and the fourth indexes, denoted SIndex 2, SIndex 3 and SIndex4, explains about 25.5\%, 12.4\% and 2\% respectively of the total variance in the data. Using the above criteria, SIndex2 and SIndex3 are composite indexes representing the following variables, SMV and SMR; and SMIndex4 is an index representing the variables $S M C / Y$, SMTOR (see Fig. 2 for the relationship between economic growth and each of the stock market development indexes). 
By using same approach, we are able to create indexes out of the four indicators to represent financial development. The first principal component, FDIndexl, explains about $73 \%$ of the total variance in the data. Whiles second, third and the fourth indexes denoted FDIndex2, FDIndex3 and FDIndex4, explains about $25 \%, 1 \%$ and $0.08 \%$ respectively of the total variance in the data. FDIndex 1 and FDIndex3 are composite indexes representing $C D / Y, C S P / Y$ and $M 2 / Y$; FDIndex2 is a composite index representing $L Q T Y / Y$; and FDIndex4 represents $C D / Y$, $C S P / Y$.

\section{Table 1}

Principal Component Analysis: Stock market development

\begin{tabular}{lccc}
\hline Principal Component & Eigenvalues & $\begin{array}{c}\text { Proportion } \\
(\%)\end{array}$ & Cumulative (\%) \\
\hline 1 & 2.975383 & 0.5951 & 0.5951 \\
2 & 1.273599 & 0.2547 & 0.8498 \\
3 & 0.617338 & 0.1235 & 0.9733 \\
4 & 0.131401 & 0.0263 & 0.9995 \\
5 & 0.002279 & 0.0005 & 1.0000 \\
\hline
\end{tabular}

\begin{tabular}{lrrrrr}
\hline Component & \multicolumn{5}{c}{ Scoring coefficients } \\
Variable & 1 & 2 & 3 & 4 & 5 \\
\hline SMC/Y & 0.535062 & 0.226117 & -0.151484 & 0.722657 & 0.342636 \\
SMTOR & 0.559525 & 0.084666 & -0.000402 & -0.669197 & 0.481600 \\
SMTV/Y & 0.575108 & 0.088943 & -0.073571 & -0.087306 & -0.805174 \\
LSV & 0.248839 & -0.614594 & 0.733087 & 0.149073 & 0.026698 \\
SMR & -0.089280 & 0.745698 & 0.658956 & -0.009873 & -0.040536 \\
\hline
\end{tabular}

Principal Component Analysis: Financial Market development

\begin{tabular}{cccc}
\hline Principal Component & Eigenvalues & Proportion (\%) & Cumulative (\%) \\
\hline 1 & 2.920676 & 0.7302 & 0.7302 \\
2 & 1.007818 & 0.2520 & 0.9821 \\
3 & 0.068204 & 0.0171 & 0.9992 \\
4 & 0.003303 & 0.0008 & 1.0000 \\
\hline
\end{tabular}

\begin{tabular}{llclc}
\hline Component & Scoring coefficients \\
Variable & 1 & 2 & 3 & 4 \\
\hline
\end{tabular}




\begin{tabular}{lrrrr}
\hline CD/Y & 0.577213 & 0.116782 & -0.411760 & 0.695443 \\
CSP/Y & 0.577248 & 0.125397 & -0.368021 & -0.718068 \\
LQTY/Y & -0.095373 & 0.981873 & 0.163424 & 0.011039 \\
M2/Y & 0.569662 & -0.081011 & 0.817500 & 0.024817 \\
& & & & \\
\hline
\end{tabular}

\section{Results of unit root tests}

Undertaking a unit root test has become a basic requirement in time series analysis. Stationarity of the series is required to ensure that shocks to the variables have no permanent effect and that the ordinary least squares estimator does not lead to spurious conclusion. We estimate Augmented Dickey-Fuller (ADF) Unit root test and complement it with Phillips-Perron (PP) unit root test to deal with issues of structural changes. The evidence on the unit root tests below show that most of the series are non-stationary at levels. In standard time series analysis, we first difference the variables to ensure stationarity. On the basis of this, we implement ARDL model since it works well for non-stationary and stationary series.

Table 2.

Results for unit root tests

\begin{tabular}{|c|c|c|c|c|}
\hline \multirow[b]{2}{*}{ Variables } & \multicolumn{2}{|l|}{ Level } & \multicolumn{2}{|c|}{$1^{\text {st }}$ Difference } \\
\hline & Constant & Constant / Trend & $\begin{array}{l}\text { Constant } \\
\text { Trend }\end{array}$ & Constant / \\
\hline$L G D P$ & -0.489775 & -2.834663 & $-3.689193 * * *$ & - \\
\hline$L C P I$ & - & $-3.390871^{*}$ & $3.582050 * *$ & \\
\hline $3.198485 * *$ & & -2.531398 & -2.145301 & - \\
\hline$L M 2$ & -0.253720 & -2.120220 & $3.547191 * *$ & \\
\hline$L S M C / G D P$ & -0.869532 & -2.102015 & -2.520007 & -2.541108 \\
\hline$L S M T R$ & -1.870661 & -2.896222 & $-4.809038 * * *$ & - \\
\hline$S M T V / G D P$ & -1.546863 & $-4.492991 * * *$ & $4.744945 * * *$ & \\
\hline$L S V$ & - & -2.265881 & $-3.689991 * * *$ & - \\
\hline $4.291097 * * *$ & & -1.538319 & $3.993400 * * *$ & \\
\hline$L M 2 / G D P$ & -0.428270 & -1.348014 & $-4.143146^{* * *}$ & - \\
\hline$L C S P / G D P$ & -1.297018 & -2.139316 & $4.411281 * * *$ & \\
\hline$C D / G D P$ & -0.880100 & -3.188961 & $-5.497774 * * *$ & - \\
\hline$L L Q T Y / G D P$ & -2.187976 & $-3.811671 * *$ & $5.440300 * * *$ & \\
\hline SMIndex1 & -1.662133 & $-3.794774 * *$ & $-2.731773 *$ & -2.650314 \\
\hline
\end{tabular}




\begin{tabular}{|c|c|c|c|c|}
\hline SMIndex2 & - & -2.516153 & $-3.083020 * *$ & -3.150900 \\
\hline $3.804748 * * *$ & & -1.151182 & $-3.796821 * * *$ & - \\
\hline SMIndex3 & - & -2.267095 & $3.796852 * * *$ & \\
\hline $3.836843 * * *$ & & -2.752575 & $-3.774416 * * *$ & - \\
\hline SMIndex4 & -2.515469 & $-3.703199 * *$ & $3.771259 * *$ & \\
\hline FDIndex 1 & -0.647901 & & $-4.048875 * * *$ & - \\
\hline FDIndex2 & -2.247432 & & $4.191742 * *$ & \\
\hline FDIndex3 & $-2.653056^{*}$ & & $-6.038244 * * *$ & - \\
\hline FDIndex4 & - & & $5.949540 * * *$ & \\
\hline $3.779442 * * *$ & & & $-5.599000 * * *$ & - \\
\hline & & & $5.519290 * * *$ & \\
\hline & & & $-4.050417 * * *$ & - \\
\hline & & & $4.114631 * *$ & \\
\hline & & & $-2.677500^{*}$ & -2.607651 \\
\hline & & & $-3.744579 * * *$ & - \\
\hline & & & $3.726672 * *$ & \\
\hline & & & $-3.927159 * *$ & - \\
\hline & & & $4.619934 * * *$ & \\
\hline & & & $-6.428092 * * *$ & - \\
\hline & & & $6.399479 * * *$ & \\
\hline
\end{tabular}

Note: * Rejection of null hypothesis of unit root at the $10 \%$ level.

** Rejection of null hypothesis of unit root at the $5 \%$ level

.*** Rejection of null hypothesis of unit root at the $1 \%$ level.

\section{Results for co-integration}

The results of the ARDL bounds test approach to co-integration are presented in Table 3. Using the real GDP as our dependent variable, we tested for co-integration on five alternative specifications for each one indicator of stock market development using one financial development indicator at a time. However, we found an evidence of cointegration in all twenty benchmark models as presented in Table 3. In the last four models, we used the four stock market indexes together with one financial development index created from principal components analysis at a time. In these models, we dropped trade openness variable to avoid having few degrees of freedom. Our stock market development indexes are orthogonal to each other; therefore we entered all the four indexes in a single equation. Again, in all the four alternative specifications reported in Table 3 , the null hypothesis of no cointegration is rejected at $99 \%$ significance level. There is thus a 
stable long-run relationship between real GDP and its determinants in all the four alternative specifications reported in Table 3. We then proceed to determine the long-run growth effects of our measures of stock market development after controlling for some other key determinants of growth. We report the results of our estimation of the long-run effects of stock market development on economic growth in Table 4 and 5. We describe the results presented by table 4 as a sensitivity analysis since it uses the stock market and financial development indicators mostly used in the literature one at a time to ascertain whether the growth effect is sensitive to proxy indicator. Table 5 is analogous to table 4 just that in table 5 , all the stock market development indexes created by principal component analysis were allowed in a single equation together with one financial development index created by the same approach at a time. In table 4, we observe that stock market capitalization/GDP has positive and statistically significant coefficient no matter what measure of financial development we use. Another measure of stock market development specifically stock market returns was seen to be positive and statistically significant throughout our sensitivity analysis with exception of table 4(b) column (5) when we used domestic credit/GDP $(C D / Y)$ as our measure of financial development.

Using the indexes created from the principal component analysis, the coefficient on the index created from the first principal component has negative and significant coefficient in column (1) - (4). The elasticity coefficient on this index in column (1) - (4) is $(-0.043380,-0.036785$, 0.049866, and -0.044279) respectively. This implies that an increase in stock market development index causes real GDP to fall by $0.043 \%, 0.037 \%, 0.05 \%$ and $0.044 \%$ in column (1) - (4) respectively. The index created from the second principal components is positive and statistically significant in column (1) - (4). The estimated elasticity coefficients on this index in column (1) (4) are $(0.017466,0.020697,0.024436$, and 0.021355$)$ respectively. This results show that a $1 \%$ 
increase in this index leads to an increase in real GDP by $0.017 \%, 0.020 \%, 0.024 \%$ and $0.021 \%$ respectively. By the same token, the index created from the third principal component has positive and statistically significant coefficient in column (1) - (4). The estimated coefficients are $(0.008538,0.010052,0.012165$, and 0.010423$)$ in column (1) - (4) respectively. Thus, a percentage increase in this index causes real GDP to increase by $0.009 \%, 0.010 \%, 0.012 \%$, and $0.010 \%$ according column 1,2, 3 and 4 respectively. The coefficients on the index created from the fourth principal component are negative and statistically significant in column (1) - (4). The elasticity coefficients on this index in column (1) - (4) are $(-0.059034,-0.054888,-0.058190$, and 0.066794). This means that a percentage increase in stock market development causes real GDP to fall by $0.06 \%, 0.055 \%, 0.06 \%$ and 0.07 respectively.

It is important to state that not only are the estimated coefficients in these four specifications statistically significant but the magnitude of the parameter estimates are economically vital. In particular, the relative sizes of positive coefficients of the stock market development indexes (SMIndex2 and SMIndex3) are not even up to $0.03 \%$ whereas the negative coefficients of indexes 1 and 4 are more than $0.03 \%$. This finding suggests that the growth effect of a positive shock to the stock market is less than a negative shock to the stock market.

In respect of the control variables, inflation, FDIndexl and FDIndex4 proved to be a robust determinant of long-run economic growth. In particular, the combine effects of $C D / Y, C S P / Y$ and $M 2 / Y$; and $C D / Y, C S P / Y$ have a significant positive impact on growth. The coefficients on these financial development indexes are positive and statistically significant in their respective models. Specifically, table 5 columns (1) and (4), the elasticity coefficient with respect to FDIndex 1 and FDIndex4 are $(0.035205$ and 0.1743950$)$. This suggests that a one percent change in financial development (FDIndexl and FDIndex4) causes real GDP to increase by $0.04 \%$ and $0.17 \%$ 
respectively. Our results also show that high levels of aggregate price level leads to a decline in economic growth while trade openness impact positively on growth. In almost every decade, the US economy faces financial crisis either from the capital or stock market. We account for this using a shift dummy. The coefficient of the financial crisis dummy is negatively significant in all the benchmark and factor models. This suggests that the US economy declines anytime it is hit by economic crisis. We do not provide results for models without a shift dummy because our results do not change significantly.

Table 3.

Bound test for co-integration

\begin{tabular}{|c|c|c|c|c|c|}
\hline \multirow{4}{*}{ boul } & \multicolumn{2}{|c|}{ F-Stat.*** } & \multicolumn{3}{|c|}{ Critical values } \\
\hline & & & \multicolumn{2}{|c|}{$99 \%$ bound } & \multirow{3}{*}{$\begin{array}{l}95 \% \\
\mathrm{I}(0)\end{array}$} \\
\hline & & & & & \\
\hline & & & & & \\
\hline$F Y\left(Y_{g}, C P I, O P E N, M 2+/ Y, S M C / Y\right.$, FINDUM $)$ & 15.29587 & 3.74 & 5.06 & & \\
\hline$F Y\left(Y_{g}, C P I, O P E N, M 2+/ Y, S M V, F I N D U M\right)$ & 13.98262 & & & 2.86 & 4.01 \\
\hline FY ( $Y_{g}, C P I, O P E N, M 2+/ Y$, SMTOR, FINDUM $)$ & 13.30759 & & & & \\
\hline$F Y\left(Y_{g}, C P I, O P E N, M 2+/ Y, S M R, F I N D U M\right)$ & 18.80767 & & & & \\
\hline$F Y\left(Y_{g}, C P I, O P E N, M 2+/ Y, S M T V / Y, F I N D U M\right)$ & 13.91018 & & & & \\
\hline$F Y\left(Y_{g}, C P I, O P E N, C D / Y, S M C / Y, F I N D U M\right)$ & 12.16762 & & & & \\
\hline$F Y\left(Y_{g}, C P I, O P E N, C D / Y, S M V, F I N D U M\right)$ & 10.52608 & & & & \\
\hline$F Y\left(Y_{g}, C P I, O P E N, C D / Y, S M R, F I N D U M\right)$ & 10.52608 & & & & \\
\hline$F Y\left(Y_{g}, C P I, O P E N, C D / Y, S M T O R, F I N D U M\right)$ & 10.73398 & & & & \\
\hline$F Y\left(Y_{g}, C P I, O P E N, C D / Y, S M T V / Y, F I N D U M\right)$ & 11.08447 & & & & \\
\hline$F Y\left(Y_{g}, C P I, O P E N, C S P / Y, S M C / Y, F I N D U M\right)$ & 14.25781 & & & & \\
\hline$F Y\left(Y_{g}, C P I, O P E N, C S P / Y, S M V, F I N D U M\right)$ & 14.20582 & & & & \\
\hline FY $\left(Y_{g}, C P I, O P E N, C S P / Y, S M T O R\right.$, FINDUM $)$ & 10.09595 & & & & \\
\hline$F Y\left(Y_{g}, C P I, O P E N, C S P / Y, S M R\right.$, FINDUM $)$ & 9.645854 & & & & \\
\hline$F Y\left(Y_{g}, C P I, O P E N, C S P / Y, S M T V / Y, F I N D U M\right)$ & 10.14018 & & & & \\
\hline$F Y\left(Y_{g}, C P I, O P E N, L Q T Y / Y, S M C / Y, F I N D U M\right)$ & 10.29848 & & & & \\
\hline$F Y\left(Y_{g}, C P I, O P E N, L Q T Y / Y, S M V, F I N D U M\right)$ & 8.459951 & & & & \\
\hline FY (Y Y, CPI,OPEN, LQTY/Y, SMTOT, FINDUM) & 8.998420 & & & & \\
\hline FY (Y Y,CPI,OPEN, LQTY/Y, SMR, FINDUM) & 10.72835 & & & & \\
\hline FY (Yg,CPI,OPEN, LQTY/Y, SMTV/Y, FINDUM) & 7.365265 & & & & \\
\hline FY ( Y $g, C P I, F D I n d e x 1, S 1, S 2, S 3, S 4$, FINDUM $)$ & 13.78172 & & & & \\
\hline$F Y\left(Y_{g}, C P I, F D I n d e x 2, S 1, S 2, S 3, S 4, F I N D U M\right)$ & 8.101876 & 3.15 & 4.43 & 2.45 & \\
\hline$F Y\left(Y_{g}, C P I, F D I n d e x 3, S 1, S 2, S 3, S 4, F I N D U M\right)$ & 17.40979 & & & & 3.61 \\
\hline$F Y\left(Y_{\mathrm{g}}, C P I, F D I n d e x 4, S 1, S 2, S 3, S 4, F I N D U M\right)$ & 13.48145 & & & & \\
\hline
\end{tabular}


Note: ***Rejection of null hypothesis of no cointegration at the $1 \%$ significance level.

Table 4

Long-run estimates of the Benchmark Model: Sensitivity Analysis (A)

\begin{tabular}{|c|c|c|c|c|c|}
\hline Variable & (1) & (2) & (3) & (4) & (5) \\
\hline Constant & $\begin{array}{c}0.219678 \\
(9.804189)^{* *}\end{array}$ & $\begin{array}{c}0.291348 \\
(9.018949)^{* *}\end{array}$ & $\begin{array}{c}0.284111 \\
(9.223329)^{* *}\end{array}$ & $\begin{array}{l}0.294990 \\
(9.234022)^{* *}\end{array}$ & $\begin{array}{c}0.265490 \\
(10.69944)^{* *}\end{array}$ \\
\hline CPI & $*$ & $*$ & $*$ & $*$ & $*$ \\
\hline Openness & $\begin{array}{l}-0.060663 \\
(- \\
3.918802)^{* * *}\end{array}$ & $\begin{array}{c}-0.064032 \\
(- \\
5.751752)^{* * *}\end{array}$ & $\begin{array}{c}-0.061071 \\
(- \\
5.707739)^{* * *}\end{array}$ & $\begin{array}{c}-0.063781 \\
(6.039683) * * \\
*\end{array}$ & $\begin{array}{c}-0.056682 \\
(- \\
6.046342)^{* * *}\end{array}$ \\
\hline $\mathrm{SMC} / \mathrm{Y}$ & $\begin{array}{l}0.137852 \\
(2.240639)^{* *}\end{array}$ & $\begin{array}{l}0.147359 \\
(2.059251)^{* *}\end{array}$ & $\begin{array}{l}0.134776 \\
(1.922749)^{*}\end{array}$ & $\begin{array}{c}0.140324 \\
(1.971088)^{*}\end{array}$ & $\begin{array}{c}0.069683 \\
(1.011631)\end{array}$ \\
\hline SMV & $\begin{array}{l}0.045680 \\
(2.852817)^{* *}\end{array}$ & & & & \\
\hline SMTOR & $*$ & & & $\begin{array}{l}-0.010030 \\
(-0.937990)\end{array}$ & \\
\hline $\mathrm{SMTV} / \mathrm{Y}$ & & $\begin{array}{c}0.006469 \\
(0.362489)\end{array}$ & & & \\
\hline SMR & & & $\begin{array}{c}0.019762 \\
(1.262251)\end{array}$ & & \\
\hline $\mathrm{M} 2+/ \mathrm{Y}$ & & & & & 0.057631 \\
\hline $\begin{array}{l}\text { FINCRDU } \\
\mathrm{M}\end{array}$ & $\begin{array}{l}-0.077783 \\
(- \\
2.286368) * * \\
-0.015039 \\
(- \\
2.446653) * * \\
\end{array}$ & $\begin{array}{c}0.066506 \\
(0.610264) \\
-0.015223 \\
(- \\
3.124706)^{* * *}\end{array}$ & $\begin{array}{c}0.061356 \\
(0.600500) \\
- \\
0.015774 \\
(- \\
3.312714)^{* * *}\end{array}$ & $\begin{array}{c}0.077897 \\
(0.734776) \\
-0.014576 \\
(-3.088075)\end{array}$ & $\begin{array}{l}(2.654540)^{* *} \\
0.019123 \\
(0.210710) \\
-0.013903 \\
(- \\
3.187091)^{* * *}\end{array}$ \\
\hline
\end{tabular}

Long-run estimates of the Benchmark Model: Sensitivity Analysis (B)

\begin{tabular}{lllccl}
\hline Variable & \multicolumn{1}{c}{$(1)$} & $(2)$ & $(3)$ & $(4)$ & \multicolumn{1}{c}{$(5)$} \\
\hline Constant & 0.322574 & 0.267543 & 0.275481 & 0.305915 & 0.319790 \\
& $(8.681914)$ & $(8.219102)$ & & $(8.780694)^{* *}$ & $(8.115484)^{* *}$ \\
CPI & -0.054821 & -0.048786 & $(8.330602)^{* *}$ & $*$ & $*$ \\
& $(-$ & $(-1.855047)^{*}$ & $*$ & -0.058291 & -0.064084 \\
Openness & $2.052433)^{* *}$ & 0.167473 & -0.049980 & $(-2.488821)^{* *}$ & $(-2.456066)^{* *}$ \\
& 0.168178 & $(2.149221)^{* *}$ & $(-1.939638)^{*}$ & 0.152608 & 0.110248 \\
SMC/Y & $(2.333427)^{*}$ & & 0.158308 & $(2.119919)^{* *}$ & $(1.326105)$ \\
& $*$ & & $(2.033183)^{*}$ & & \\
SMV & 0.031031 & & & -0.007278 & \\
& $(1.826935)^{*}$ & & & & \\
SMTOR & & 0.006078 & & & \\
\hline
\end{tabular}


$\mathrm{SMTV} / \mathrm{Y}$

$(0.312469)$

SMR

$\mathrm{CD} / \mathrm{Y}$

$-0.015321$

$(0.754352)$

0.049436

$\begin{array}{lll} & & (-0.477777) \\ \mathrm{MINCRDU} & -0.056014 & -0.016668 \\ & (-1.290006) & (- \\ & -0.015938 & 2.923955) * * \\ & (- & * \\ & 2.932187) * * & \\ & *\end{array}$

$(1.653450)$

0.009706

$(-0.371596) \quad(0.040846) \quad(0.298743)$

$-0.016833 \quad-0.014611-0.014154$

$(-$

$\left.2.890026)^{* * *} \quad 2.628665\right)^{* *}$

Long-run estimates of the Benchmark Model: Sensitivity Analysis (C)

\begin{tabular}{|c|c|c|c|c|c|}
\hline Variable & (1) & (2) & (3) & (4) & (5) \\
\hline Constant & $\begin{array}{c}0.252122 \\
(2.682027) *\end{array}$ & $\begin{array}{c}0.302903 \\
(7.910237)\end{array}$ & $\begin{array}{c}0.304134 \\
(7.925420)^{* *}\end{array}$ & $\begin{array}{c}0.309529 \\
(9.372902)^{* *}\end{array}$ & $\begin{array}{c}0.293059 \\
(7.850335)^{* *}\end{array}$ \\
\hline CPI & $\begin{array}{l}-0.043716 \\
(-1.761048)^{*}\end{array}$ & $\begin{array}{l}-0.066359 \\
(-\end{array}$ & $\begin{array}{l}* \\
-0.065690\end{array}$ & -0.061663 & $\begin{array}{l}* \\
-0.068691\end{array}$ \\
\hline Openness & $\begin{array}{l}0.129078 \\
(2.903695)^{* *}\end{array}$ & $\begin{array}{l}4.831996)^{* *} \\
*\end{array}$ & $\begin{array}{l}(- \\
4.853534) * * *\end{array}$ & $\begin{array}{l}(- \\
6.077221)^{* * *}\end{array}$ & $\begin{array}{l}(- \\
2.135887)^{* *}\end{array}$ \\
\hline $\begin{array}{l}\mathrm{SMC} / \mathrm{Y} \\
\mathrm{SMV}\end{array}$ & $\begin{array}{l}* \\
0.056199 \\
(2.668181)^{* *}\end{array}$ & $\begin{array}{c}0.165640 \\
(2.066568)^{* *}\end{array}$ & $\begin{array}{l}0.153277 \\
(1.908028)^{*}\end{array}$ & $\begin{array}{l}0.146230 \\
(2.304410)^{* *}\end{array}$ & $\begin{array}{l}0.095367 \\
(0.993292)\end{array}$ \\
\hline SMTOR & & & & $\begin{array}{l}-0.028694 \\
(-2.795711)\end{array}$ & \\
\hline SMTV/Y & & $\begin{array}{c}-0.015194 \\
(-0.645362)\end{array}$ & & & \\
\hline SMR & & & -0.004308 & & \\
\hline $\mathrm{CSP} / \mathrm{Y}$ & -0.110592 & & $(-0.178746)$ & & $\begin{array}{c}0.087063 \\
(1.745790)^{*}\end{array}$ \\
\hline $\begin{array}{l}\text { FINCRDU } \\
\mathrm{M}\end{array}$ & $\begin{array}{l}(- \\
2.370289)^{* *} \\
-0.012186 \\
(- \\
2.712478)^{* * * *}\end{array}$ & $\begin{array}{l}0.065819 \\
(0.559654) \\
-0.017219 \\
(- \\
3.490625) * * \\
*\end{array}$ & $\begin{array}{l}0.033095 \\
(0.243233) \\
-0.016573 \\
(- \\
3.301815)^{* * *}\end{array}$ & $\begin{array}{l}0.159015 \\
(1.861182) \\
-0.016931 \\
(- \\
4.024676) * * *\end{array}$ & $\begin{array}{l}0.011465 \\
(0.291592) \\
-0.012115 \\
(- \\
2.140564)^{* *}\end{array}$ \\
\hline
\end{tabular}

Long-run estimates of the Benchmark Model: Sensitivity Analysis (D) 


\begin{tabular}{|c|c|c|c|c|c|}
\hline Variable & (1) & (2) & (3) & (4) & (5) \\
\hline Constant & $\begin{array}{l}0.255502 \\
(7.951068)^{* *}\end{array}$ & $\begin{array}{c}0.275545 \\
(7.493221)\end{array}$ & $\begin{array}{l}0.259829 \\
(6.716495)^{* *}\end{array}$ & $\begin{array}{c}0.290846 \\
(7.178343)^{* *}\end{array}$ & $\begin{array}{c}0.242401 \\
(8.177147)^{* * *}\end{array}$ \\
\hline CPI & $\begin{array}{l}* \\
-0.055648\end{array}$ & $\begin{array}{l}-0.054911 \\
(-\end{array}$ & $\begin{array}{l}-0.056274 \\
(-\end{array}$ & $\begin{array}{l}* \\
-0.059350\end{array}$ & $\begin{array}{c}* \\
-0.050105\end{array}$ \\
\hline Openness & $\begin{array}{l}(- \\
5.073131)^{* * *}\end{array}$ & $\begin{array}{l}4.528874)^{* *} \\
*\end{array}$ & $\begin{array}{l}4.353020)^{* *} \\
*\end{array}$ & $\begin{array}{l}(- \\
5.434062) * * *\end{array}$ & $\begin{array}{c}(- \\
4.401064)^{* * *}\end{array}$ \\
\hline $\mathrm{SMC} / \mathrm{Y}$ & $\begin{array}{l}0.150916 \\
(1.882178)^{*}\end{array}$ & $\begin{array}{c}0.154121 \\
(1.926064)^{*}\end{array}$ & $\begin{array}{l}0.183009 \\
(2.081313)^{* *}\end{array}$ & $\begin{array}{c}0.216549 \\
(2.839730)^{* *}\end{array}$ & $\begin{array}{l}0.083792 \\
(0.984028)\end{array}$ \\
\hline SMV & $\begin{array}{l}0.068903 \\
(2.025257)^{*}\end{array}$ & & & * & \\
\hline SMTOR & & & & & \\
\hline SMTV/Y & & $\begin{array}{c}0.018838 \\
(0.829988)\end{array}$ & & $\begin{array}{l}-0.022570 \\
(-1.797176)^{*}\end{array}$ & \\
\hline LQTY/Y & & & $\begin{array}{l}0.016767 \\
(0.747031)\end{array}$ & & $\begin{array}{c}0.058483 \\
(2.040732)^{*}\end{array}$ \\
\hline $\begin{array}{l}\text { FINCRDU } \\
\text { M }\end{array}$ & $\begin{array}{l}-0.065990 \\
(-0.622146) \\
-0.016445 \\
(- \\
3.630644)^{* * *}\end{array}$ & $\begin{array}{l}-0.009858 \\
(-0.221616) \\
-0.016039 \\
(- \\
2.938714)^{* *} \\
*\end{array}$ & $\begin{array}{l}-0.092515 \\
(-0.681280) \\
-0.015785 \\
(- \\
3.118433)^{* *} \\
*\end{array}$ & $\begin{array}{l}0.087022 \\
(0.759974) \\
-0.014018 \\
(- \\
2.891093)^{* * *}\end{array}$ & $\begin{array}{c}-0.019365 \\
(-0.478043) \\
-0.014757 \\
(- \\
2.867566)^{* * *}\end{array}$ \\
\hline
\end{tabular}

Values in parenthesis are $t$-statistics.

* Significance at the $10 \%$ level

** Significance at the $5 \%$ level.

***Significance at the $1 \%$ level.

Table 5

Long-run estimates of the Factor Model

\begin{tabular}{lllll}
\hline Variable & \multicolumn{1}{c}{$(1)$} & \multicolumn{1}{c}{$(2)$} & \multicolumn{1}{c}{$(3)$} & \multicolumn{1}{c}{$(4)$} \\
\hline Constant & 0.280509 & 0.244630 & 0.226491 & 0.243842 \\
& $(11.37840)^{* * *}$ & $(5.155806)^{* * *}$ & $(5.726408)^{* * *}$ & $(5.266950)^{* * *}$ \\
CPI & -0.048016 & -0.045568 & -0.040678 & -0.041118 \\
& $(-5.510618)^{* * *}$ & $(-5.093273)^{* * *}$ & $(-4.866362)^{* * *}$ & $(-4.844070)^{* * *}$ \\
FDIndex1 & 0.035205 & & & \\
& $(1.944798)^{*}$ & & & \\
FDIndex2 & & -0.007059 & & \\
& & $(-1.068986)$ & & \\
FDIndex3 & & & -0.004592 & \\
& & & $(-0.137211)$ & \\
\hline
\end{tabular}




\begin{tabular}{lclll}
\hline FDIndex4 & & & & \\
& & & & 0.174395 \\
SMIndex1 & & & $(1.909494) *$ \\
& -0.043380 & -0.036785 & -0.049866 & -0.044279 \\
SMIndex2 & $(-2.693305)^{* *}$ & $(-1.889099)^{*}$ & $(-3.041923) * * *$ & $(-2.554652)^{* *}$ \\
& 0.017466 & 0.020697 & 0.024436 & 0.021355 \\
SMIndex3 & $(4.084487)^{* * *}$ & $(3.900636) * * *$ & $(4.861204)^{* *}$ & $(4.393749)^{* * *}$ \\
& 0.008538 & 0.010052 & 0.012165 & 0.010423 \\
SMIndex4 & $(2.310140)^{* *}$ & $(2.253766)^{* *}$ & $(3.263205)^{* * *}$ & $(2.585979) * *$ \\
& -0.059034 & -0.054888 & -0.058190 & -0.066794 \\
FINCRDUM & $(-2.965509)^{* * *}$ & $(-2.727723)^{* *}$ & $(-3.355028)^{* * *}$ & $(-3.494391)^{* * *}$ \\
& -0.014672 & -0.013260 & -0.010849 & -0.007522 \\
& $(-3.539849)^{* * *}$ & $(-2.884232)^{* * *}$ & $(-2.712691)^{* *}$ & $(-1.460716)^{*}$ \\
\hline
\end{tabular}

Values in parenthesis are $t$-statistics.

* Significance at the $10 \%$ level

** Significance at the $5 \%$ level.

*** Significance at the $1 \%$ level.

\section{Conclusion}

This paper empirically examines the long-run relationship between economic growth and stock market development using US data. Our analysis was conducted based on five alternative indicators of stock market development. We used principal component analysis to reduce the number of indicators from five to four while retaining approximately $100 \%$ of the total variance in the data. Also, the four indexes created by the principal component analysis were used to check the robustness of our results. The results suggest that the growth effect of stock market development is sensitive to the choice of indicator. For instance, using either the stock market capitalization to GDP ratio or stock market returns, we found a significant positive association with economic growth. However, we cannot make same conclusion when one uses either the ratio of total value of trades on the major stock exchanges to GDP, stock market turnover ratio to proxy for stock market development as the coefficient on these variables were found to be statistically insignificant The indexes extracted from principal component analysis show that our results are robust since it confirms the sensitivity of the growth effect to the choice of proxy. We also found 
that using alternative financial market development indicators have practically no influence on our results. This findings show that stock market development is a conceptual term, thus, representing it with single indicators make it impossible to identify which stock market development indicators have positive growth effects.

\section{References}

Adu, G., Marbuah, J. and Mensah, T. (2013). "Financial development and economic growth in Ghana: Does the measure of financial development matter?" Review of Development Finance Volume 3, Issue 4, pp.192-203

Ahmed S. (1998). Comment on "The legal environment, banks and long-run economic growth" Journal of Money and Credit Bank., 30, pp. 614-620

Allen, F., Qian, J., and Qian, M. (2005). "Law, finance and economic growth in China" Journal of Financial Econmics., 77, pp. 57-116

Arestis, P, Demetriades, P.O. and Luintel, K. B. (2001). Financial Development and Economic Growth: The Role of Stock Markets, Journal of Money, Credit and Banking, Vol. 33, No. 1, pp. 16-41

Atje, R, and Jovanovich, B.(1993). "Stock markets and development", European Economic. Review, 37 (2-3), pp. 632-640

Bencivenga, V. R., Smith, B. D. and Starr, R. M. (1996). Equity markets, transactions costs and capital accumulation: an illustration. World Bank Economic Review, 10, 241-265. Levine, R. (1991).“Stock Markets, Growth, and Tax Policy,”Journal of Finance, 46(4), pp. 1445-65.

Beck, T., Levine, R. and Loayza, N. (2000). "Finance and the source of growth", Journal of Financial Economics, 58, pp. 261-300

Beck, T. and Levine, R. (2004), "Stock markets, banks, and growth: panel evidence”, Journal of Banking and Finance, 28 pp. 423-442

Choe, I.C, and Moosa, A. (1999) "Financial system and economic growth: the Korean experience”, World Dev., 27, pp. 1069-1082

Christopoulos, D.K. and Tsionas, E., G. (2004). "Financial development and economic growth: evidence form panel unit root and cointegration tests", Journal of Development Economics, 7, pp. 55-74 
Devereux, M.B., and Gregor W. S. (1994). "International Risk Sharing and Economic Growth." International Economic Review 35, pp:535-50.

Fisman, R. and Love, I. (2003).“Trade Credit, financial intermediary development, and industry growth” J. Financ., 58 (2003), pp. 353-374

Garrestsen, H., Lensink, R., and Sterken, E.(2004). "Growth, financial development, societal norms and legal institutions", Journal of International Financial Markets, Institutions and Money, 14, pp. 165-183

Goldsmith, R.W. (1969). "Financial Structure and Development". New Haven, Conn.: Yale University Press.

Greenwood, J. and Smith B. Forthcoming. "Financial Markets in Development and the Development of Financial Markets." Journal of Economic Dynamics and Control.

Gupta, K., L. (1984).’Finance and Economic Growth in Developing Countries”, Croom Helm, London

Harris, R.D. F. (1997).'Stock markets and development: a re-assessment”, European Economic Review, 41, pp. 139-146

Holmstrom, B., and Tirole J. (1993). "Market Liquidity and Performance Monitoring." Journal of Political Economy 101(4, August):678-709.

King, R.G. and Levine, R.(1993a) "Financial Intermediation and Economic Development," in Financial intermediation in the construction of Europe. Eds.: COLIN MAYER AND XAVIER VIVES. London: Centre for Economic Policy Research, pp. 156-89.

1993b. "Finance and Growth: Schumpeter Might Be Right," Quarterly Journal of. Economics, 108(3), pp. 717-37

Kyle, A.S. (1984). "Market Structure, Information, Futures Markets, and Price For- mation." In Gary G. Storey, Andrew Schmitz, and Alexander H. Sarris, eds., Inter- national Agricultural Trade: Advanced Readings in Price Formation, Market Structure, and Price Instability. Boulder, Colo.: Westview

Levine R., and Zervos S. (1998). Stock markets, banks, and economic growth Am. Econ. Rev., 88 (3), pp. 537-558

Levine, R. and Zervos, S. (1996). Stock Market Development and Long-Run Growth, The World Bank Economic Review, Vol. 10, No. 2, A Symposium Issue on Stock Markets and Economic Development, pp. 323-339

Morck, R, Shleifer A., and Vishny R.W. (1990a). "Do Managerial Ob- jectives Drive Bad Acquisitions?" Journal of Finance 4, pp:31-48. . 
1990b. "The Stock Market and Investment: Is the Market a Sideshow?" Brookings Papers on Economic Activity 2:157-215.

Neusser, K, and Kugler, M. (1998)."Manufacturing growth and financial development: evidence from OECD countries", Review of Economic Statistics., 80, pp. 638-646

Obstfeld, M. (1994). "Risk-Taking, Global Diversification, and Growth." American Economic Review 84(5, December):1310-29.

Pan L., and Mishra V. (2018). "Stock market development and economic growth: Empirical evidence from China”, Economic Modelling 68, pp. 661-673

Pesaran, M. H, and Smith, R. (1995). "Estimating long-run relationships from dynamic heterogeneous panels", Journal of Econometrics, 68 (1995), pp. 79-113

Pesaran, M. H, and Shin, Y. (1998).” An autoregressive distributed-lag modelling approaches to cointegration analysis" Economics Soc. Monogr., 31, pp. 371-413

Pesaran, M. H, Shin, Y and Smith, R. M., (2001) "Bounds testing approaches to the analysis of level relationship”, Journal of Applied Economics., 16 (3), pp. 289-326

Rajan, R.G. and Zingales, L. (1998). "Financial dependence and growth", American Economic Review, 88, pp. 559-586

Rousseau, P., L., and Vuthipadadorn, D. (2005). "Finance, investment and growth: time series evidence from 10 Asian economies”, Journal of Macroeconomics., 27, pp. 87-106

Rousseau, P., L. and Wachtel, P. (2000). "Equity market and growth, cross country evidence on timing and outcomes", Journal of Banking and Finance, 24, pp. 1933-1957

Shleifer, A., and Summers L. (1988). "Breach of Trust in Hostile Takeovers." In Alan Auerbach, ed.,. Corporate Takeovers: Causes and Consequences. Chicago: University of Chicago Press

$\mathrm{Xu}, \mathrm{Z}$. (2000). "Financial development, investment, and economic growth" Economics Inquiry, 38 (2000), pp. 331-344 